\title{
SOME INEQUALITIES OF DIFFERENTIAL POLYNOMIALS
}

\author{
JUNFENG XU, HONGXUN Yi AND ZHANLIANG ZHANG
}

Abstract. In this paper, we consider the value distribution of the differential polynomials $f^{n} f^{(k)}-$ 1 where $n(\geqslant 2), k$ are positive integers, and obtain some estimates only by the reduced counting function.

Mathematics subject classification (2000): 30D35, 26D10. distribution.

Keywords and phrases: Meromorphic function, differential polynomials, Nevanlinna theory, value

\section{REFERENCES}

[1] A. M. Alotaibi, On the zero of af $f^{(k)}-1$, Complex Var. Theory Appl. 49 (2004), no. 13, 977-989.

[2] W. BERGEILER AND A. EREMENKO, On the singularities of the inverse to a meromorphic function of finite order, Rev. Mat. Iberoamericana., 11(1995), 355-373.

[3] H. H. ChEN AND M. L. FANG, On the value distribution of $f^{n} f^{\prime}$, Sci. China. Ser. A., 38(1995), $789-798$.

[4] J. CLUNIE, On integral and meromorphic functions, J. London Math. Soc., 37(1962), 17-27.

[5] F. GACKSTATTER, I. LAINE, Zur Theorie der gewöhnlichen Differentialgleichungen im Komplexen, Ann. Polon. Math., 38 (1980), 259-287.

[6] W. W. GoluBEW, Voresungen Über differentialgleichung im komplexem, Berlin, Dduerscher Verlag der Wissenschaften, 1958.

[7] W. K. HAYMAn, Meromorphic functions, Clarendon Press, Oxford, 1964.

[8] W. HENNEKEMPER, Über die Wertverteilung von $\left(f^{k+1}\right)^{(k)}$, Math. Z., 177(1981), 375-380.

[9] X. J. HuAng AND Y. X. Gu, On the value distribution of $f^{2} f^{(k)}$, J. Aust. Math. Soc., 78(2005), $17-26$.

[10] I. LAINE, Nevanlinna theory and complex differential equations, Walter de Gruyter, Berlin-New York, 1993.

[11] J. P. WANG, On the distribution of $f f^{(k)}$, Kyungpook Math. J., 46(2006), 169-180.

[12] J. F. Xu And Z. L. Zhang, Note on normal family, J. Inequal. Pure and Appl. Math., Volume 7, Issue 4, Art 133, 2006.

[13] K. YAMANOI, The second main theorem for small functions and related problems, Acta Math., 192 (2004), 225-294.

[14] C. C. YAng AND P. C. Hu, On the distribution of $f f^{(k)}$, Kodai Math. J., 19 (2) (1996), 157-167.

[15] C. C. YAng And H. X. YI, Uniqueness Theory of Meromorphic Functions, New York, Dordrecht, Boston, London, 2003.

[16] L. YANG, Value distribution theory, Springer, Berlin, Heidelberg, New York, 1993.

[17] Z. L. Zhang, W. LI, Picard exceptional values for two class differential polynomials, Acta Math. Sinica., 34(1994), 828-835. 